\title{
A Study on the University Placement System for Gifted Children in
} Turkey

\author{
Kamil Arif Kırkıç ${ }^{1}$ \\ ${ }^{1}$ Faculty of Education, Istanbul Sabahattin Zaim University, Istanbul, Turkey \\ Correspondence: Kamil Arif Kırkıç, Faculty of Education, Istanbul Sabahattin Zaim University, Istanbul, Turkey. \\ E-mail: kamil.kirkic@izu.edu.tr
}

Received: January 27, 2019

Accepted: March 14, 2019 Online Published: March 29, 2019

doi:10.5539/jel.v8n3p59

URL: https://doi.org/10.5539/jel.v8n3p59

\begin{abstract}
There is no special university entrance exam for gifted students in Turkey. Their only option is to complete the standard university entrance exam at the end of their final year in high school. This system of entrance exams does not benefit gifted students. Other universities around the world support such students in the following two ways: through honor programs and early college entrance systems. This paper examines these two types of programs that support gifted students, and it employs a cross-cultural comparison between Turkey and the United States, China, and Finland. Furthermore, the paper proposes a multi-step model for educating gifted students and for improving the university entrance exam process. The new type of entrance exam that we propose could be employed in Turkey to support gifted students entering university. By implementing the proposed university entrance system, gifted students will become more effective in life for themselves as well as society.
\end{abstract}

Keywords: giftedness, university entrance program, gifted students, gifted education

\section{Introduction}

"Children/students that are identified by experts who are outperforming in intelligence, creativity, arts, leadership capacity or special academic areas than their peers" are deemed to be gifted, according to the Turkish Ministry of National Education (MEB, Milli Eğitim Bakanlığı, 2017).

Gifted education has long been identified as a crucial part of education systems around the world. For example, Germany and France provided special education programs for gifted students before World War I. This education style accelerated and was improved in different parts of Germany (Enç, 2008, cited in Çaylak \& Y1lmaz, 2009). The first exclusive school for gifted children was opened in the United States in the 20th century (Nazzaro, 1977, cited in Robins, 2010). Asian countries also have a history of focusing on gifted education. In 1978, the University of Science and Technology of China began offering an early entrance program for accelerated students. Later, twelve universities adopted this system in 1985, although now only two of them serve gifted students (Pang, 2012). South Korea takes legal steps to protect the educational rights of gifted children and schools employ education methods, such as Science, Technology, Engineering, Mathematics (STEM) to support gifted children, especially in high school (Brown \& Wishney, 2017). Singapore also prioritizes the education of gifted students. Singapore sees gifted students as a highly improved human resource and integrates them into special gifted education programs starting in the third grade. After completing these programs, gifted students can enter college without completing any other exams (Brown \& Wishney, 2017).

While many countries have recognized the importance of supporting gifted students, there is not always an agreement on how the term "gifted" is defined or measured. Exam scores or other academic activities cannot accurately measure giftedness. Instead, giftedness should be defined as a combination of social, academic, and life skills, as well as creativity. Giftedness can be measured in terms of an individual's performance in various fields. Therefore, instead of defining giftedness within limited words and phrases, it can better be explained in terms of individual performance levels in different areas (Witty, 1958, cited in Renzulli, 1978).

Renzulli (2003) argued that students' teachers or families can identify gifted students, and when their IQ is higher than 120, other factors are also important to call a student gifted. The ability to use intelligence in different ways is crucial in the definition of "gifted". Elements, such as creativity and social skills and their 
combination are not only bounded by a person's nature but also a person's experiences with family, school, and social life.

Countries have crafted varying regulations for gifted students' education at the university level. Some have preferred to establish equality by integrating them in regular classrooms. Other societies see gifted students as an important human resource for their country and have created special university entrance programs and honor programs to support them. To create an equal environment for gifted students, governments should consider their learning speed and prepare special curriculum to support their talents.

However, the lack of a general definition of "giftedness" continues to dominate the field. However, Sternberg (2004) argued that there is consensus around the following areas: giftedness involves more than just IQ; it has non-cognitive components (e.g., motivation); the environment is crucial to realize potential; there are multiple forms of giftedness, therefore, one kind of assessment or provision is too narrow; and measures of giftedness need to be evaluated. Another definition of giftedness can be expressed as the state of being a state of interaction of a person by using his/her potential with the environment (Silverman, 2018).

The problem of education of gifted students in Turkey is an invisible but bleeding wound. There are problems in integrating the giftedness phenomenon into the Turkish education system. In addition, tests for gifted students mostly focus on academic talents and not on social skills. A considerable challenge for gifted students is that their potential is not always discovered, and even if it is, the education system still creates barriers for them.

In the Turkish educational system, there are a limited number of schools for gifted students, and there is no specific option for them to finish high school early. In addition, often, talents of these students are wasted in the school due to poor curriculum design and teachers' lack of awareness about giftedness. Moreover, there is no statistical research on gifted students in Turkey; there is not even any clear data on how many gifted students exist in the country.

One example of a gifted education program in Turkey is the Science and Art Centers (BILSEM). BILSEM has 106 education centers in 80 cities. At BİLSEM, gifted students are selected through exams and interviews. Some examples of courses offered at BILLSEM are fine arts, literature, space sciences, sustainability, robotics, mind games, archeology, and city culture. Areas of interest are determined according to students' talents. It is noteworthy that BİLSEM is not like a full-day school. Students attend lectures outside school hours. The Turkish Ministry of National Education (MONE) states that there are 8,000 students in BILSEM programs (Sar1 \& Ögülmüsş, 2014). BİLSEM's main goal is not to serve as a test system for university entrance exams but to discover potential in children and teach them how to think critically. From this perspective, BİLSEM is not a test preparation center. Since there is no special program for gifted students to enter university before their coevals, the BILSEM program ends in the third year of high school to allow students to prepare for university entrance exams in their last year. In contrast, other countries have university honor programs and early university entrance processes for gifted students, which assist them in the transition to university life.

Developing countries such as Turkey, which need more technological integration in society, should focus more on gifted students' education and how such education can be achieved effectively. Two ways to improve this system are to offer summer programs and special entrance programs for gifted students who will enter university. Allowing students to develop their interests will help them be successful in university. Unfortunately, the current Turkish education system classifies "successful" students as students who get high scores on test-based exams and "gifted" students are those who receive high scores on IQ tests. Evidently, intelligence is an important aspect of giftedness; however, there is also value in social skills, leadership, teamwork, commitment, and creativity.

This study begins with a discussion of the definition of "giftedness". Subsequently, it provides an overview of gifted students' education in Turkey. A cross-cultural comparison of university entrance exam processes in Turkey, China, the United States, and Finland follows. Lastly, the paper proposes specific solutions for establishing a university entrance process and university programs for gifted students as well as suggesting a multi-step model to improve gifted education and the university entrance process in Turkey.

\section{Conceptual Framework and Methodology}

\subsection{Giftedness}

Giftedness has been defined in various ways among researchers. Renzulli (1978) argued that, "giftedness consists of an interaction among three basic clusters of human traits - these clusters being above average general abilities, high levels of task commitment, and high levels of creativity." As Renzulli states, giftedness is not bounded by intelligence. Gardner and Hatch (1989) contended that there are seven intelligence types and a person is not restricted to one category. They claimed that intelligence depends on both a person's capacity or 
genetics and also their environment (Gardner \& Hatch, 1989). From these definitions, we can conclude that gifted people are intelligent in different ways and that the environment has a significant impact on giftedness. A gifted child's intelligence and talents should be discovered and nurtured by both the family and the school. Focusing only on academics can decrease the creativity of gifted children and the interest of gifted children in subjects in which they are competent.

\subsection{Giftedness in Education}

Schools are important tools that affect the development process of gifted children. The talents and behaviors of gifted children should not be overlooked because they display different types of intelligence. For example, a child who has more rhythmic intelligence than mathematical intelligence can be seen as "unsuccessful" if teachers only assess them with bounded rationality. If gifted children cannot find support and guidance at an early age, their talents may be wasted. Therefore, the support that children receive in kindergarten, elementary school, and secondary school should continue into university.

Nevertheless, high school systems do not always support the development of students' talents and instead pressure them to enter college. Research on student depression before university entrance exams in several countries has shown that students feel pressure before taking their exams (LaFraniere, 2013; Thomas, 2016; Yildirim, Ergene, \& Munir, 2007). This pressure leads to decreased time spend on social life, decreased school success, and an increase in communication problems, especially in third- or fourth-year high school students (Kumandaş \& Kutlu, 2014). Besides school, children can attend different training centers as per their interest but the sustainability of this system is debatable. Because of the stress of university exams in their final year of high school, students must choose between focusing on their exams or on their personal interests.

The Turkish high school curriculum does not focus on children's talents and a four-year high school education is mandatory for all citizens. In addition, in the last year of high school, children complete university entrance exams. There is no specific option for gifted students to enter university earlier or to take an exemption from the university entrance exams. Gifted children can attend different courses outside of school but there is not enough space to implement their talents in schools. This situation is not only a problem in Turkey but is also a problem in the rest of the world. Very few education systems around the world care about gifted teaching and understand the value of gifted students. In some countries, such as the United Kingdom, teaching gifted students differently is viewed negatively - as inequality to non-gifted students. Some schools for talented children were closed in the United Kingdom (Reid \& Boettger, 2015). Although gifted students are a minority, education systems must take their needs into consideration; ignoring these students is an injustice.

\subsection{Methodology}

Comparative research is a research methodology in the social sciences that aims to make comparisons across different countries or cultures; it involves the comparison of two or more things with a view to discovering something about one or all of the things being compared (Jones, 1985). Cross-national comparisons are the most commonly used comparative method in which similar or different countries or one's own country can be compared to a chosen set of countries.

This study aims to cross-compare the university entrance systems of different countries in a desire to propose a more efficient model for channeling gifted students to university degrees. The countries were chosen using a purposive sampling technique (Fraenkel, Wallen, \& Hyun, 2011).

Turkey is in the sample because a new university entrance system is needed in the country for gifted students. The criterion for the choice of other countries was that, as indicated by the existing literature, these countries have an advanced education system for gifted students (Wolfensberger, 2015; Dai \& Steenbergen-Hu, 2015).

Although using both quantitative and qualitative data is legitimate in a comparative study (Teddlie \& Tashakkori, 2009), data from the literature review of giftedness and university entrance systems were employed in this paper. Literature review is the examination of visual and auditory pieces such as articles, documents, maps, pictures, and photographs on the related topic (Cepni, 2014). Hence, the data for this study are designated as information obtained from academic or non-academic documents that exist in the literature about the topic of interest.

\section{Results}

\subsection{Overview of Gifted Education in Turkey}

The Turkish education curriculum is not contemporary and cannot cope with the modern, developing world. Final year high school students have to choose between focusing on their education and practicing for the university entrance exam. In addition, since students rely on the material that they learned throughout high 
school for the university entrance exam, a student's entire high school career can be very stressful. To create a less stressful and more effective education system, a STEM educational style should be integrated into Turkish education. Furthermore, the education of gifted children in Turkey would be more effective if programs such as summer school and designated university entrance exams were offered more than once a year, which would allow gifted students the opportunity to enter university earlier.

Gifted students can be integrated into the Turkish education system better through more practical application of theoretical topics and adopting different university entrance models. As an example, those who are interested in STEM curriculum can combine theory and application. Moreover, a student who is talented in social sciences, entrepreneurship, leadership, or management can focus on projects of interest. For example, gifted students with interpersonal intelligence can participate in social responsibility projects (Gardner \& Hatch, 1989).

While offering more practical applications in the curriculum would benefit gifted students, summer school would also provide these children with rich learning opportunities. For many years the Turkish education system has incorporated long holiday breaks into the academic calendar. According to the European Commission (2015), most countries across Europe begin the school year in September and holidays vary among countries. Germany, the Netherlands, and the United Kingdom each have six weeks of holiday while Turkey, Italy, and Latvia have up to 13 weeks of holiday each year (European Commission, 2015). According to a survey of middle school and high school parents in Turkey, $42.3 \%$ of parents state that holidays are long and $48.1 \%$ state that the total number of school days in a year is not enough (Gökçe, 2012). Moreover, Gökçe's research showed that some parents believe that while the length of the school year is adequate, the quality of education is low.

\section{Discussion}

\subsection{Summer School Programs for Gifted Children}

In countries that have long summer breaks, such as Turkey, summer schools can be an effective mechanism to broaden the horizons of students and to encourage learning. In particular, high school students who attend a university summer program can receive good education and also learn how the university system works. Summer schools at colleges or universities can allow gifted students to enter university earlier. In 1961, Prospect Heights High School announced a program to collaborate with State University of New York at Potsdam University. Eleven female students gained entrance to this program after completing interviews and exams. Only girls were selected for this program because in that decade female attendance at college was low. After completing the program, the students stated that summer school was beneficial for both learning about college and learning how to use theory in practice (Teitelbaum, 1962). Although Teitelbaum's research on university-backed summer schools focused on the program as a motivational tool for girls, it could also help students to become familiar with university culture and to select fields of study in college.

Today, different colleges around the world offer summer schools for high school students; Harvard, UCLA, State University of New York, University of Berkeley, University of Chicago, Oxford, and Cambridge Academy are some examples. There are many universities in Turkey, such as Sabancı University and Boğaziçi University, among others, that have summer school programs that have summer school programs where the courses include arts and sports as well as academic courses. Summer school curricula are flexible and not all classes are mandatory for each student. These programs offer classes across different categories from law to medicine. In countries with extended summer holidays, such as Turkey, summer schools for high school students are beneficial, not only from the student perspective but also from the university perspective. Universities have a chance to meet potential students and to learn about their expectations from university life. In addition, some of these universities, such as Koç University, transfer credits from summer school classes. However, these summer schools play an introductory role in high school education system. If used effectively, they could have an impressive effect on gifted education.

By using the design of summer schools mentioned above, a new university entrance system can be designed for gifted students. After 9th and 10th grades, gifted students could attend summer schools for two months, i.e., a total of four months. In these summer schools - that would focus on various academic areas - gifted students could choose courses based on their interest. Gifted students could learn about university and choose their academic areas of interest at the end of the first summer course after 9th grade.

4.2 Approaches to Gifted Education and University Entrance Systems in Turkey, China, United States, and Finland

\subsubsection{Turkey}

In the 1940s, Turkish students were selected for university from examinations that they completed during their 
secondary education. By the 1950s, some universities started to create their own essay-style exams; however, they were difficult to evaluate objectively (İçbay, 2005). As the number of applicants to university increased over time, authorities decided to create a multiple-choice exam. Moreover, the Turkish university entrance exam was unexpectedly changed in the 2017-2018 academic year. Prior to the changes, university candidates who achieved the YGS (Higher Education Entrance Exam) could enter a vocational school of higher education which often had a limited number of faculties. Additionally, some students who studied in vocational high school had the opportunity to continue directly to vocational departments in college without completing the YGS. Every June, university candidates completed at least one and no more than five exams, according to the department in which they hoped to study. However, in the 2017-2018 academic year, the YÖK (Council of Higher Education) announced that students would only take one exam in June. This type of single-session exam was part of the education system before 2010. The rapidly changing university entrance exam scenario in Turkey is also a reason for stress among university candidates.

According to Öğrenci Seçme Yerleştirme Merkezi [ÖSYM] (Student Selection and Placement Center), in 2017, in terms of the university entrance exam results, the quota of approximately 300,000 for high school graduates was not met. In spite of this, students who were not satisfied with their university entrance exam results had to wait for one year to retake the exam. According to a study on candidates' university entrance examination preparation, only $28.8 \%$ of candidates were not anxious, and among those whose anxiety levels were medium or high, $78.1 \%$ spent less than two hours on social activities (Ünalan, Çifçili, Dinç, Akman, \& Topçuoğlu, 2017). This research indicates that the university entrance exam puts stress on students. One of the most important effects of this stress can be the limit of repeating the exam only once a year. Students should be able to choose when they are ready to take the exam.

To create a sustainable and judicious system for university entrance examination, university entrance exam should be offered more than once a year, and students should have the opportunity to complete the exam in their third year. In particular, students with high academic abilities should have the chance to complete the exam in the earlier years of high school.

Offering the entrance exam more than once a year can give gifted students a chance to start their university education earlier. Offering more than one exam per year helps not only gifted students but actually helps all students enter university earlier. This situation may also decrease the stress level for students and give them time to think about their talents and professions. Additionally, if authorities allow students to enter university earlier, justice for all students can be achieved because under the current system, students have the option to delay university attendance but not to enter university earlier. Reconstructing the system is not only beneficial for gifted students but also for every student who wants to enter university. Offering more opportunities to complete the university entrance exam would allow gifted students to enter university earlier and would also likely decrease students' stress levels. Of course, there should be some limitation on the exam because, as clearly seen from ÖSYM's example, some students took the university entrance exam before they were ready, and they did not register at any university. Other factors such as economic conditions, geographical conditions, and health issues may also affect the decision to register for university. There should be three university entrance exams per year, as universities can accept students during the three different semesters: fall, spring, and summer.

\subsubsection{China}

Education is valued in the Chinese society, and gifted education is a component of the Chinese school system. Among the Organization for Economic Co-operation and Development countries, China has one of the highest PISA exam results (OECD, 2016). China's education system mandates that every child should complete nine years of education. Students have the option of continuing on to higher education by completing an exam called "gaokao" conducted by the National Examination Authority within the Ministry of Education (Devey, De Lian, \& Higgins, 2010). This exam contains multiple-choice questions, fill in the blanks questions, writing, and calculations (Devey et al., 2010). In addition, China offers honors programs and early entrance processes. Early entrance to university has been in place since 1978 at University of Science and Technology of China, which is one of three schools that offers gifted education (Dai \& Steenbergen-Hu, 2015). Students who applied to the early entrance process finished their pre-college education at least one year before their peers and are very successful at entering world-ranked universities such as Harvard, MIT, and Stanford (Dai \& Steenbergen-Hu, 2015); among these honors programs, $70 \%$ have focused on science (Li \& Kitagaki, 2012). Overall, China is a country that places importance on gifted education. In higher education, gifted students can benefit from different programs. Additionally, researchers implied that there are positive results of early access to higher education, as gifted students work and study in top-ranked colleges around the world (Dai \& Steenbergen-Hu, 2015; Li \& Kitagaki, 2012). 


\subsubsection{United States}

Trow contended that the American higher education system is unique (1991, cited in Davies \& Hammack, 2005). Higher education and university entrance exams in the United States are not centralized the way exams are in Turkey or China. An entrance exam is not the only step to be accepted to university. Writing essays, collecting reference letters, taking exams, such as the SAT or TOEFL or the GMAT or GRE for graduate school, are all highly important components of the application process. According to Times Higher Education (2017), in 2017, seven of the top ten universities in the world were in the United States; of these seven, three have honors programs. Honors programs are designed to serve gifted students with a broad from across various disciplines. These programs accept a limited number of students and enjoy small class sizes. This creates an environment that is more open to discussion and practice. In addition, honors students write a thesis or complete a final project to graduate. Each student has a special advisor to guide them according to their individual talents. Although these programs accept students from different disciplines, they have common courses based on conducting research, academic discussion, and creative activities. The honors program in the United States aim to encourage gifted students through a targeted academic curriculum and through research opportunities at the undergraduate level. Honors programs can provide crucial support for gifted students and provide balance in the university selection process.

\subsubsection{Finland}

Due to its high rating among OECD countries on the PISA exam, Finland's education system has gained attention (OECD, 2016). Keskinen, Tiuraniemi, and Liimola (2008) explained that Finland's education system is quite different from the rest of the European education system. At age seven, children begin a nine-year primary school program after which they can either study in vocational school or upper secondary school. Students apply to universities according to their interests and complete an entrance exam. Students can apply online through university website. Each school creates its own entrance exam and some departments make their own exams while others participate in a common exam. Students can apply to different departments; however, they are accepted only at one department in each university. In Finland's education system, there are no laws that grant special education for gifted students; however, due to Finland's value of education, individualism, and freedom of choice, students are educated according to their talents, an approach that is the main goal of gifted education (Tirri \& Kuusisto, 2013). Moreover, some schools accept small numbers of students, for example, International Baccalaureate programs or schools are based more on science and mathematics learning (Tirri \& Kuusisto, 2013). Finland's emphasis on education provides gifted students with easy access to resources and helps them improve themselves according to their talents. There are honors programs at three universities in Finland (Wolfensberger, 2015). Thus, a gifted student has a chance to get an education according to his or her talents from primary school through a university in Finland.

\subsection{University Entrance Types and University Programs for Gifted Students}

University honor programs and early university entrance processes are two different approaches to help gifted students adapt to university. University honor programs are special programs designed for gifted students to effectively use their talents in academics. University honors programs appear most frequently in the United States, Canada, and across Europe; there are also some countries in Asia with university honors programs. The early university entrance process has been initiated in some countries and with this system, university candidates can register without waiting until their final year in high school.

\subsubsection{University Honor Programs}

Honor programs were established to ensure equality between gifted students and average students (Olsen, 1961). University honors programs target talented students from different major programs. High academic achievement is expected during the admission process. Honors programs are available to students throughout their university career.

University honors programs are different from regular university programs in some ways. Students can have the opportunity to conduct one-on-one research with their advisors; thus, they can specialize in a specific topic. Another benefit of honors programs is that students who are at similar academic levels receive education in a shared classroom. Scholarships and grants provide honors students with support in research activities and projects. Completion of honors programs appear on students' diplomas. Different kinds of travel opportunities are provided in honors programs so that students may attend national or international congresses or seminars. Mentoring is another part of honors programs, and students are motivated according to their talents. Different researchers have discussed the structure of honors programs and how they differentiate from traditional undergraduate programs (Baur, 1969; Olsen, 1961). 
Honors programs are not widespread in Turkey as they are in the United States, Europe, Asia, or Canada. Turkey should focus more on gifted education and honors programs to develop high-quality human resources.

\subsubsection{Early University Entrance Process}

The early university entrance process is available for talented and gifted students in different universities. A variety of research has been conducted on this process (Lupkowski, Whitmore, \& Ramsay, 1992; Noble \& Drummond, 1992; Shepard, 2009). Early university entrance allows gifted students to register for university without going to high school or to enter university at least one year earlier than their current status. Washington University's Nancy Robinson Center for Young Scholars has an Early Entrance Program (EEP) for gifted students, which was the earliest of such programs, established in 1997 (Hertzog \& Chung, 2015). At Washington University, there is both an honors program and an early entrance process. The main difference between the two is that the EEP accepts students before they enroll in high school while the honors program accepts students during their tenth year of high school. In addition, there are colleges, such as Johns Hopkins Center of Talented Youth, that provide an education for talented students. In the first two years, students take grade 9 and 10 classes; in last two years, they can complete up to 60 credits in college coursework.

Other countries also offer EEPs. In China, an EEP was established in 1978 at the University of Science and Technology of China (Dai \& Kuo, 2015). Similar to the Washington University program, the University of Science and Technology of China's School of the Gifted Young People provides gifted education.

\section{Conclusion}

\subsection{A Model for University Entrance for Gifted Students}

Being a gifted child in Turkey is very difficult at every level of the education system because schools are built for the general population. Therefore, gifted children and their families have considerable barriers when these children move on to higher education. To overcome such barriers, gifted students should be evaluated in terms of their unique talents and their type of giftedness. We propose that gifted students will be more beneficial to the society as well as the world if they are given unique university entrance examinations. An effective university entrance system for gifted students has seven steps:

1) Planning summer courses: Create a detailed plan of university-led summer courses for gifted students, planned at the end of the 9th grade. Different departments from different faculties design a two- or three-week program for the students based on courses that best represent the departments.

2) Placement: Register students in the first summer course based on their interests and rules determined by each university. Parents of candidate students provide all documents, reference letters, etc. to the departments. In terms of the placement criteria, the departments of each faculty choose the students and inform their parents.

3) Predicting potential: Understand skills and capabilities of gifted students at the end of the first summer course, which would be taken at the end of the 9th grade.

4) Program placement: Placement of gifted students into the second summer course is done after completing the 10th grade, based on achievement levels and interests at the end of the academic year.

5) Evaluation: Apply a detailed measurement and evaluation system during the end of the second summer course to decide whether each gifted student is successful or not in his/her area of interest, which was chosen at the end of the first summer school session.

6) Admission: On the basis of the results obtained in the fifth step, gifted students choose academic programs and universities. They should complete preference lists and submit them to universities of their choice.

7) Personal registration: Parents of gifted students register their children at the chosen university. The fiscal issues and other processes are completed by the parents. The university assigns an advisor for the student. All learning materials and ID cards are given to the student.

Not enough attention is paid to the education of gifted students around the world. However, if governments fail to notice the value in improving gifted education, a major source that could be used for the development of the country will be wasted. Considering the fact that Turkey suffers from "brain drain," gifted education is a crucial topic for discussion. In addition, if gifted students are forced to adapt to the general curriculum, inequality starts to occur. Thus, in education, new opportunities should be provided for gifted students. The first step to support such students is to create a summer program that eases their transition to university life as well as provides challenging learning opportunities that can help them choose their areas of academic interest. 


\section{Acknowledgments}

I would like to express my sincere appreciation of Ayşe Perihan Kırkıç for her valuable support, dedicated contribution, and limitless patience.

\section{References}

Baur, J. E. (1969). Learning in an honors program. Improving College and University Teaching, 7, 291-296. https://doi.org/10.1080/00193089.1969.10532899

Brown, E., \& Wishney, L. R. (2017). Equity and excellence: Political forces of gifted students in the United States and abroad. Global Education Review, 4, 22-23.

Çaylak B., \& Yılmaz, M. (2009). Parents' views toward contribution of science and art center to students' success in science and technology lesson. Mustafa Kemal University Journal of Social Sciences Institute, 6, 369-383.

Dai, Y. D., \& Steenbergen-Hu, S. (2015). Special class for the gifted young: A 34-year special class for the gifted young: a 34-year experimentation with early college entrance programs in China. Roeper Review, 37, 9-18. https://doi.org/10.1080/02783193.2014.975882

Dai, Y. D., \& Kuo, C. C. (2015). Gifted Education in Asia Problems and Prospects. NC Information Age Publishing, Inc.

Devey, G., De Lian, C., \& Higgins, L. (2010). The university entrance examination system in China. Journal of Further and Higher Education, 31, 385-396. https://doi.org/10.1080/03098770701625761

Davies, S., \& Hammack, F. M. (2005). The Channeling of student competition in higher education: Comparing Canada and the U.S. Journal of Higher Education, 76, 89. https://doi.org/10.1353/jhe.2005.0003

European Commission. (2015). Organisation of school time in Europe Primary and secondary general education. Retrieved May 14, 2018, from http://eacea.ec.europa.eu/education/eurydice/documents/facts_and_figures/186EN.pdf

Fraenkel, J. R., Wallen, N. E., \& Hyun, H. (2011). How to Design and Evaluate Research in Education (8th ed.). McGraw-Hill Education.

Gardner, H., \& Hatch, T. (1989). Multiple intelligences go to school: educational implications of the theory of multiple intelligences. Educational Researcher, 18, 4-10. https://doi.org/10.2307/1176460

Gökçe, F. (2012). Öğretmen ve velilerin, öğrencilerin okulda geçirdikleri zaman, ders ve dinlenme süreleri ile tatiller ve okul dönemleri konusundaki görüşleri. [Opinions of Teachers and Parents about Time Spent by Students at School, Lesson Hours, Break Times, Holidays and School Terms]. Kuram ve Uygulamada Ĕ̈itim Bilimleri, 12, 2541-2560.

Hertzog, N. B., \& Chung, R. U. (2015). Outcomes for students on a fast track to college: Early college entrance programs at the University of Washington. Roeper Review, 37, 39-49. https://doi.org/10.1080/02783193.2014.976324

İçbay, M. A. (2005). A SWOT analysis on the university entrance examination in Turkey: A case study. Mersin University Journal of the Faculty of Education, 1, 126-140.

Jones, C. (1985). Patterns of Social Policy. Taylor \& Francis.

Kirst, M. W. (1978). Reflections on education in China. Phi Delta Kappan, 60, 124-125.

Koeskinen, E., Tiuraniemi, J., \& Liimola, A. (2008). University selection in Finland: How the decision is made. International Journal of Educational Management, 22, 638-650. https://doi.org/10.1108/09513540810908557

Kumandaş, H., \& Kutlu, Ö. (2014). Yükseköğretime öğrenci seçmede ve yerleştirmede kullanılan sınavların oluşturduğu risk faktörlerinin okul başarısı üzerindeki etkileri. [The Risk factors caused by exams used for student selection and placement into higher education on the academic performance]. Türk Psikoloji Dergisi, $29,15-31$

LaFranie, S. (2014). Failure is not an option: China's annual college entrance exam can make or break young lives. (n.d.) In the Free Library. Retrieved May 19, 2018, from https://www.thefreelibrary.com/Failure+is+not+an+option\%3a+China\%27s+annual+college+entrance+exa m+can...-a0316663422 
Li, D., \& Kitagaki, I. (2012). On training excellent students in China and the United States. Journal of the National Collegiate Honors Council, 13(2), 119-128.

Lupkowski, A. E., Whitmore, M., \& Ramsay, A. (1992). The Impact of early entrance to college on self-esteem: A preliminary study. Gifted Child Quarterly, 36, 87-90. https://doi.org/10.1177/001698629203600206

Milli E. B. (2017). Child development and education: Giftedness, special ability and inclusion. Retrieved May 17 , 2018 , from http://megep.meb.gov.tr/mte_program_modul/moduller/\%C3\%9Cst $\% \mathrm{C} 3 \% \mathrm{BCn} \% 20 \mathrm{Zek} \% \mathrm{C} 3 \% \mathrm{~A} 21 \% \mathrm{C} 4 \% \mathrm{~B}$ 1 lar\%20ve\%20\%C3\%96zel\%20Yetenekliler.pdf

Noble, K. D., \& Drummond J. E. (1992). But what about the prom? Students' perceptions of early college entrance. Gifted Child Quarterly, 36, 106-111. https://doi.org/10.1177/001698629203600209

Organization for economic co-operation and development. (2016). PISA 2015: PISA Results in Focus.

Olsen, J. K. (1961). The honors program at Kent State University. Educational Research Bulletin, 40, 224-231.

Öğrenci Seçme Yerleştirme Merkezi (Student Selection and Placement Center) [ÖSYM]. (2017). Retrieved May 12, 2018, from http://www.osym.gov.tr/TR,6547/arastirma-yayin-ve-istatistikler.html

Pang, W. (2012). The Actiotope model of giftedness: A useful model for examining gifted education in China's universities. High Ability Studies, 23, 89-91. https://doi.org/10.1080/13598139.2012.679101

Reid, E., \& Boettger, H. (2015). Gifted education in various countries of Europe. Slavonic Pedagogical Studies Journal, 4. https://doi.org/10.18355/PG.2015.4.2.158-171

Renzulli, J. S. (1978). What makes giftedness? reexamining a definition (pp. 180-184). Kappan.

Renzulli, J. S. (2003). The three-ring conception of giftedness: Its implications for understanding the nature of innovation. The International Handbook on Innovation. https://doi.org/10.1016/B978-008044198-6/50007-3

Robins, J. H. (2010). An explanatory history of gifted education: 1940-1960. Doctoral dissertation, Baylor University, USA. Retrieved March 22, 2018, from https://baylorir.tdl.org/baylorir/bitstream/handle/2104/7946/Jennifer_Robins_phd.pdf?sequence=4\&isAllow ed $=\mathrm{y}$

Sarı, H., \& Öğülmüş, K. (2014). Bilim ve Sanat Merkezlerinde (BILSEM) Karşılaşılan Sorunların Öğretmen ve Öğrenci Görüşleri Açısından Değerlendirilmesi. [Evaluation of the problems faced by teachers and students in science and art centers]. Uluslararası Türk Eğitim Dergisi, 2, 254-265.

Shepard, S. J., Foley N. M., \& Doobay, A. F. (2009). Early entrance to college and self-concept: Comparisons across the first semester of enrollment. Journal of Advanced Academics, 2, 40-57. https://doi.org/10.1177/1932202X0902100103

Silverman, L. K. (2013). Giftedness 101. [Adobe Digital Editions]. Retrieved August 13, 2018, from http://eds.a.ebscohost.com/eds/ebookviewer/ebook/

Sternberg, R. (2004). Culture and intelligence. American Psychologist, 59, 325-338 https://doi.org/10.1037/0003-066X.59.5.325

Teddlie, C, \& Tashakkori, A. (2009). Foundations of Mixed Methods Research: Integrating Quantitative and Qualitative Approaches in the Social and Behavioral Sciences. Los Angeles: Sage.

Teitelbaum, D. (1962). Participation in an experimental college summer study program by a group of high school juniors. Retrieved August 13, 2018 from https://files.eric.ed.gov/fulltext/ED029716.pdf

Thomas, S. (2016). Stress in adolescents attempting entrance exams to professional courses in relation to regularity of routine, Study Habits and Parental Expectations. Indian Journal of Health and Wellbeing, 7, 251-253.

Tirri, K., \& Kuusisto E. (2013). How Finland serves gifted and talented pupils. Journal for the Education of Gifited, 36, 84-96. https://doi.org/10.1177/0162353212468066

Ünalan P., Çifçili, S., Dinç, D., Akman, M., \& Topçuoğlu, V. (2017). Üniversite Sınavına Girecek Olan Öğrencilerde Sınav Kaygısı Düzeyi, Sosyal Etkinlikler ve Rehberlik Hizmetini Kullanma Durumu. [Test anxiety level, social activities and utilization of counseling services among the students who will take the university entrance exam]. Nobel Medicus, 13. 
Wakefield, J. F., O'Reilly, A. E., \& Pass, A. D. (2016). Giftedness and cognitive development. Salem Press Encyclopedia of Health.

Wolfensberger, V. C. M. (2015). Talent development in European higher education honors programs in the Benelux, Nordic and German-Speaking Countries. Springer. Retrieved March 22, 2018, from https://ink.springer.com/content/pdf/10.1007/978-3-319-12919-8.pdf

World University Rankings 2016-2017. (2017). Retrieved March 22, 2018, from https://www.timeshighereducation.com/world-university-rankings/2017/world-ranking\#!/page/0/length/25/s ort_by/rank/sort_order/asc/cols/stats

Yıldırım, İ., Ergene, T., \& Munir, K. (2017). High rates of depressive symptoms among senior high school students preparing for national university entrance examination in Turkey. International Journal on School Disaffection, 4, 35-44. https://doi.org/10.18546/IJSD.04.2.07

\section{Copyrights}

Copyright for this article is retained by the author, with first publication rights granted to the journal.

This is an open-access article distributed under the terms and conditions of the Creative Commons Attribution license (http://creativecommons.org/licenses/by/4.0/). 